\title{
APLIKASI AIR KELAPA SEBAGAI ADITIF ALAMI BAGI PENINGKATAN MUTU PRODUK CAKALANG ASAP (CAKALANG FUFU) KHAS SULAWESI UTARA
}

\author{
Djuhria Wonggo, Silvana D. Harikedua, dan Eunike Louisje Mongi.
}

\begin{abstract}
ABSTRAK
Diseminasi produk teknologi ke masyarakat dengan aplikasi air kelapa sebagai aditif alamiah bagi peningkatan mutu produk cakalang asap (cakalang fufu) khas Sulawesi Utara bertujuan supaya dihasilkan produk ikan asap ( $f u f u$ ) yang bermutu dan aman dikonsumsi serta menjadikan mitra kerja pada kelompok percontohan bagi kelompok pengolah ikan lainnya. Target luaran adalah: tersedianya 3 bak beton dengan 3 fungsi berbeda (bak penampungan dan pencucian ikan, bak perendaman dan bak penampungan limbah); Adanya rumah pengasapan yang lebih memadai sehingga ada efisiensi penggunaan bahan bakar dari pengolah; Serta adanya produk ikan asap dengan mutu yang lebih baik dan harga yang lebih kompetitif. Ini ditandai dengan adanya tekstur yang lebih kompak, warna yang lebih menarik tanpa penambahan pewarna, citarasa yang khas ikan asap, serta penurunan kadar histamin. Untuk pencapaian tujuan tersebut maka metode yang digunakan adalah survei, penyuluhan, pelatihan termasuk didalamnya perbaikan fisik usaha pengasapan ikan, pendampingan dan evaluasi. Hasil pengamatan dan pengalaman di lapangan, para pengusaha pengolah ikan fufu mempunyai kebiasaan yang perlu dilestarikan dan juga ada hal-hal membutuhkan waktu yang cukup untuk mengubah kebiasaan yang selama ini mereka lakukan dimana kebiasaan ini tidak perlu ditiru. Teknologi yang ditransfer ke masyarakat belum sepenuhnya diterima, dan hal ini membutuhkan waktu untuk penyuluhan yang teratur dan berkelanjutan.
\end{abstract}

Kata kunci: air kelapa, mutu ikan cakalang asap.

\section{PENDAHULUAN}

Kelurahan Molas adalah salah satu Kelurahan di Kecamatan Bunaken dan terletak di bagian utara Kota Manado. Luas Kelurahan Molas adalah 7,98 $\mathrm{km}^{2}$. Dilihat dari segi topografinya, Kelurahan Molas berbentuk dataran dan sedikit perbukitan. Secara umum Kelurahan Molas berada pada ketinggian $\pm 3 \mathrm{~m}$ di atas permukaan laut. Dari segi geografis, Kelurahan Molas bagian Barat berbatasan langsung dengan Teluk Manado/Kecamatan Kepulauan Bunaken. Mitra berdomisili di kelurahan Molas, lingkungan 5 yang berada di daerah pesisir pantai. Mitra menjual hasil pengolahan ikan asap ke Pasar Bersehati yang terletak di Kelurahan Calaca, Kecamatan Wenang, Kota Manado $( \pm 8 \mathrm{~km})$ dari tempat domisili mitra.

Jumlah penduduk di Kelurahan Molas adalah 5.025 orang dari $1.549 \mathrm{KK}$. Keluarga penerima Raskin adalah $100 \mathrm{KK}$ atau $6,45 \%$ dari total KK. Jumlah ibu-ibu produktif adalah 300 orang, Balita 225 orang dan Batita adalah 50 orang. Terdapat 1 sekolah TK, 3 Sekolah Dasar (SD) dan 1 Sekolah Menengah Pertama (SMP). Pekerjaan masyarakat meliputi: nelayan 70\%, tani 20\%, Pegawai Negeri Sipil (PNS) 5\% dan lainnya $5 \%$. Khusus untuk mitra, ada 5 orang pekerja untuk pengolahan ikan asap. 1 orang tamat dari SMP dan 4 lainnya lulusan SD. Semuanya adalah kepala keluarga yang menggantungkan hidupnya dari hasil mengolah ikan asap ataupun berkebun.

Perekonomian masyarakat di Kecamatan Bunaken pada umumnya ditopang oleh dua mata pencarian utama, yaitu hasil-hasil laut dan pertanian. Sektor pertanian secara umum meliputi kopra, pisang, mangga dan umbiumbian. Hasil laut dari kegiatan perikanan meliputi ikan-ikan pelagis seperti ikan Deho, Cakalang dan Ikan Terbang serta ikan-ikan karang lainnya seperti Bobara, Barongan, Goropa. Ada 5 usaha pengolahan ikan asap di Kelurahan Molas dan salah satunya adalah mitra dalam kegiatan diseminasi ini. Sebagian besar hasil pengolahan ikan asap dijual ke Pasar Bersehati yang terletak di Kelurahan Calaca, Kec. Wenang, Kota Manado $( \pm 8 \mathrm{~km})$ dari tempat domisili mitra. Konsumen yang membeli sebagian besar adalah masyarakat yang berdomisili di Kecamatan Wenang dan Singkil. Setiap minggu, pengolah bisa melakukan 3 kali produksi. Jumlah satu kali produksi sekitar 300-400 gepe ikan asap. Satu (1) ekor ikan berukuran 5-6 $\mathrm{kg}$ dapat dibentuk menjadi 2 gepe. Pengolah biasanya membeli ikan-ikan murah yang sudah tidak laku terjual sebagai ikan segar. Umumnya saat ini 1 ekor ikan 
Cakalang yang masih segar di pasar dijual dengan harga Rp. 20.000,- \pm Rp.5.000,-. Harga ikan akan berfluktuasi tergantung pada musim ikan dan cuaca. Menurut mitra, jika beruntung mereka bisa mendapatkan ikan seharga Rp. 12.500 ,- per ekor. Hasil produksi ikan asap per gepe bisa dijual seharga Rp.25.000,- \pm Rp.5.000,- (tergantung ukuran ikan dan harga ikan mentah). Jadi secara kasar, untuk 1 ekor ikan segar (Rp. 12.500,-) yang telah menjadi 2 gepe ikan cakalang asap (Rp.25.000,- $\times 2=\mathrm{Rp}$. $50.000,-)$ mitra dapat memperoleh keuntungan sebesar Rp. 37.500,-

Sasaran program ini adalah untuk meningkatkan mutu produk ikan asap dengan memberi efek pada rasa dan teksturnya, menambah umur simpannya dan secara otomatis memberikan harga jual ikan asap yang lebih kompetitif. Pengolahan ikan cakalang asap di kelurahan Molas masih bersifat konvensional dan berpotensi membahayakan kesehatan, karena pengolah masih menggunakan ikan-ikan bermutu rendah tanpa penanganan yang baik, memberikan pewarna makanan pada ikan untuk menarik perhatian konsumen, dan menggunakan rumah asap yang kurang memadai.

Penggunaan ikan-ikan yang bermutu rendah khusus pada ikan cakalang bisa memicu terjadinya keracunan makanan akibat terbentuknya produk histamin. Ikan Cakalang dan ikan scombroidea lainnya secara alami mengandung asam amino histidin bebas yang tinggi. Tanpa penanganan (penerapan suhu dingin) yang baik, asam amino ini dapat terurai menjadi histamin (zat yang menyebabkan gangguan pernafasan, gatal-gatal, dan alergi pada manusia) oleh kerja enzim histidin dekarboksilase. Dengan kata lain masyarakat tidak menerapkan adanya teknologi refrigerasi atau tindakan pendinginan dan pembekuan pada bahan baku mereka. Disamping itu, penelitian di tahun 1995 tentang penggunaan air kelapa untuk pengurangan kadar histamin pada ikan Cakalang menyimpulkan bahwa ikan yang direndam pada air kelapa memiliki kadar histamin $50 \%$ lebih rendah dibandingkan dengan ikan yang tidak direndam dengan air kelapa (Wonggo, 1995). Hasil penelitian ini memberi petunjuk adanya solusi untuk meningkatkan kualitas bahan baku awal sebelum pengolahan ikan cakalang asap.

Secara alami proses pengasapan panas dengan kombinasi penerapan suhu tinggi dan komponen pengawet asap dapat memberikan tekstur yang kompak, citarasa khas asap, dan warna coklat kemerahan karena terjadi reaksi enzimatik antara protein dan karbohidrat pada daging ikan dengan komponen asap dibantu dengan proses pengasapan itu sendiri. Karena kurangnya pemahaman dalam proses perubahan komposisi kimia daging ikan selama proses pengasapan, pengolah masih menggunakan pewarna sebelum ikan diasap supaya hasil akhir ikan cakalang asap memiliki warna menarik yang disukai konsumen.

Berdasarkan pengamatan di lapangan, dalam proses pengasapan pengolah menggunakan berbagai macam kayu sisa, yang bisa didapat dari kebun maupun dari limbah buangan rumah tangga. Kondisi rumah asap yang masih terbuka ini memberi dampak pada banyaknya bahan bakar yang diperlukan untuk proses pengasapan ikan sehingga waktu pengasapan juga menjadi lebih panjang. Pengolah seperti belum menyadari bahwa untuk mendapatkan efisiensi bahan bakar dan waktu serta untuk menjaga kualitas ikan asap yang baik, diperlukan konstruksi rumah asap yang tepat.

Dalam merumuskan masalah, tim duduk bersama dengan mitra berdiskusi untuk menentukan skala prioritas masalah yang perlu mendapat solusi dengan kegiatan ini. Berdasarkan analisis situasi yang dikemukakan di atas, secara garis besar permasalahan mitra dapat dikategorikan sebagai berikut:

a. Aspek Produksi: produksi dengan mutu bahan baku yang rendah menghasilkan produk ikan asap dengan mutu yang rendah dengan harga yang murah tetapi memberi potensi berbahaya bagi konsumen.

b. Aspek Teknologi: Belum adanya penerapan suhu dingin yang maksimal untuk mempertahankan mutu awal bahan baku yang baik. Mitra belum mendapat informasi bahwa tahu bahwa air kelapa dapat meningkatkan mutu ikan yang sudah kurang segar lagi. Mitra belum memperhatikan dengan baik bahwa rumah pengasapan dengan konstruksi yang tepat dapat memberi efisiensi dalam proses pengolahan ikan asap.

Target yang diharapkan tercapai adalah penyuluhan dan pelatihan ini dapat memberi pemahaman baru bagi pengolah ikan asap, keluarga pengolah ikan asap dan masyarakat sekitar tentang manfaat perendaman ikan pada 
air kelapa, penerapan rantai dingin, penerapan sanitasi dan higienis, dan penggunaan rumah asap tertutup terhadap perbaikan mutu ikan cakalang asap. Diharapkan mitra bisa menjadi contoh bagi kelompok pengolah asap lain yang berada di kelurahan Molas dan di dalam 5 tahun mendatang bisa menjadi panutan bagi pengolah ikan asap di Kecamatan Bunaken ataupun di kota Manado umumnya. berikut:

Solusi masalah yang ditawarkan sebagai

1. Aspek Produksi: karena kurangnya pengetahuan dan pemahaman tentang perubahan kimia apa saja yang terjadi pada daging ikan selama proses penangkapan, distribusi, dan proses pengolahan ikan asap, maka tim berniat melakukan penyuluhan sekaligus demonstrasi dengan alat peraga tentang perbedaan mutu ikan segar yang ditangani dengan baik dan ikan yang tidak mengalami proses pendinginan yang baik. Penyuluhan juga akan memberi informasi tentang bahaya dari penggunaan ikan yang sudah menurun mutunya bagi konsumen. Hal ini dimaksudkan agar hasil olahan ikan asap dari kelurahan Molas akan lebih dikenal masyarakat Manado, memiliki daya jual yang bersaing, dan aman dikonsumsi masyarakat.

2. Aspek Teknologi: tim membuat 3 bak beton dengan fungsi berbeda yaitu bak penampungan dan pencucian ikan, bak perendaman ikan dengan air kelapa, dan bak penampungan limbah sehingga proses pengolahan ikan asap dapat diperbaiki. Dengan adanya 3 bak ini diharapkan adanya kesadaran bagi pengolah untuk menerapkan prinsip sanitasi dan higienis demi perbaikan mutu produk. Tim juga berencana memperbaiki konstruksi rumah asap yang ada di lapangan sehingga bisa menghemat bahan baku yang digunakan.

Target luaran yang diharapkan terjadi pada kelompok pengolah ikan asap di Kelurahan Molas ini yaitu:

1. Tersedianya 3 bak beton dengan 3 fungsi berbeda. (bak penampungan dan pencucian ikan, bak perendaman dan bak penampungan limbah).

2. Adanya rumah pengasapan yang lebih memadai sehingga ada efisiensi penggunaan bahan bakar dari pengolah

3. Adanya produk ikan asap dengan mutu yang lebih baik dan harga yang lebih kompetitif.
Ini ditandai dengan adanya tekstur yang lebih kompak, warna yang lebih menarik tanpa penambahan pewarna, citarasa yang khas ikan asap

\section{METODE}

Metode pelatihan dilakukan berdasarkan metode pembelajaran orang dewasa (otodidak) dan dilaksanakan secara klasikal dengan memberikan teori dan praktek melalui ceramah dan diskusi kelompok secara terarah $(\mathrm{FGD}=$ Focus Group Discussion). Dalam pelaksanaannya teori diberikan sebanyak $25 \%$ dan praktek $75 \%$. Pelaksanaannya selama 8 (delapan) bulan. Bulan pertama persiapan kegiatan, bulan kedua pelaksanaan pelatihan selama 6 hari (4 jam/hari), pemantauan evaluasi monitoring dan pendampingan pada bulan berikutnya sampai selesai.

Instruktur/penceramah adalah staf pengajar di Fakultas Perikanan dan Ilmu kelautan Program Studi Teknologi Hasil Perikanan yang bidang keahliannya Penanganan Hasil Perikanan. Peserta adalah anggota kelompok pengolah ikan fufu Cempaka yang juga merupakan mitra kerja.

Proses latihan menggunakan alat audio visual (LCD dan Wireless), kertas plano dan spidol. Masing-masing peserta dibagikan materi dalam bentuk makalah, buku notes serta alat tulis menulis. Partisipasi mitra dalam kegiatan ini adalah kehadiran anggota kelompok selama kegiatan ini dilaksanakan. Tim juga dapat memperoleh bahan baku (ikan) dari mitra dan dihargai sesuai dengan harga penjualan yang berlaku. Kelompok mitra diharapkan dapat mempraktekan sendiri hasil pelatihan ini dan tim akan selalu mendampingi serta melakukan pemantauan setiap bulannya hingga kegiatan ini berakhir.

Adapun metode pelaksanaan yang akan di terapkan pada program ini yakni memberikan penyuluhan dan pelatihan (praktek kerja) terhadap mitra yang beranggotakan 5 orang. Kegiatan yang akan dilaksanakan sebagai berikut:

\section{Penyuluhan}

Materi penyuluhan disampaikan kepada pengolah ikan fufu (cakalang asap) meliputi kebersihan sarana pengolahan serta lingkungannya dan penanganan ikan sebelum proses pengasapan yang mencakup: (1) Pencucian dengan air mengalir; (2) Perendaman dalam air kelapa. Penyuluhan berisikan tentang 
bagaimana melakukan proses pengasapan yang baik dan benar yang mencakup suhu, lama pengasapan serta jenis bahan bakar yang baik. Pada kegiatan ini tim memperkenalkan teknologi tepat guna kepada mitra yaitu perendaman dalam air kelapa yang sebelumnya sudah diteliti oleh Wonggo (1995) dan Montolalau (1995). Kegiatan penyuluhan ini di harapkan dapat merubah cara pikir serta kebiasaan lama yang dilakukan oleh kelompok pengolah sehingga dapat meningkatkan kualitas sumber daya manusia ke arah yang lebih baik dan menghasilkan produk ikan fufu yang berdaya saing.

\section{Pelatihan}

Pelatihan dan praktek pengolahan dilakukan setelah kegiatan penyuluhan yang diselingi dengan tanya jawab dari peserta atau mitra. Kegiatan pelatihan dimaksudkan sebagai praktek penerapan iptek. Kegiatan ini dilakukan oleh tim yang dibantu oleh beberapa mahasiswa $S_{1}$ yang sedang menyelesaikan tugas akhir.

Pelatihan yang akan dilakukan yaitu:

a. Pencucian menggunakan air mengalir.

Pada tahap pelatihan ini tim memperlihatkan kepada mitra bagaimana cara pencucian yang baik dan benar sehinggan darah dan sisa-sisa penyiangan tidak nampak lagi. Karena menurut informasi mitra, selama ini proses pencucian yang mereka terapkan tidak menggunakan air mengalir. Pemahan mereka bahwa ikan juga nantinya akan diasapkan(kena asap panas) dan bakteri akan mati. Dalam tahap penyuluhan sebelumnya, tim sudah menginformasikan bahwa berdasarkan penelitian yang telah dilakukan, bahan baku yang tidak ditangani dengan baik pada saat pencucian akan menyebabkan rasa serta tekstur yang kurang baik bahkan mengurangi masa simpan. Hal ini disebabkan karena bahan baku tidak bersih (darah dan sisa siangan masih melekat) dan walaupun sudah mengalami proses pemanasan (pengasapan), bakteri tahan panas masih dapat hidup.

\section{b. Perendaman dengan air kelapa}

Menurut penelitian Wonggo (1995), jenis bahan perendam mempengaruhi kadar histamin daging ikan cakalang dan ikan layang. Dimana proses perendaman ikan dalam air kelapa selama \pm 10 menit dapat menurunkan kadar histamin pada kedua jenis ikan tersebut. Lebih lanjut dijelaskan bahwa bahkan ikan yang pada awalnya sudah mengandung histamin akan mengalami penurunan kadar histamin jika direndam dalam air kelapa. Montolalu (1995), komponen gizi lainnya yang masih dapat dipertahankan walaupun sudah mengalami pemanasan (pengasapan) yaitu asam lemak tak jenuh omega 3 .

Proses perendaman dilakukan dalam 1 bak penampung sehingga dapat menampung banyak ikan. Dalam hal ini tim menyediakan 3 bak penampung bagi mitra, bak penampung dan pencucian ikan, bak untuk perendaman pada air kelapa dan bak terakhir untuk menampung air limbah sisa pencucian dan sisa air kelapa. Tim menginformasikan bahwa mitra dapat memperoleh air kelapa dari kelompok usaha yang mengolah bahan makanan dari daging kelapa. Sehingga air kelapa merupakan limbah bagi kelompok ini, namun dengan kerjasama yang baik dapat dimanfaatkan oleh kelompok pengolah ikan fufu. Hal juga merupakan suatu kegiatan pemanfaatan limbah kelapa (air kelapa) selain tempurung dan sabut kelapa. Hal penting yang perlu diketahui oleh pengolah bahwa air kelapa yang tidak dimanfaatkan akan memberikan polusi besar bagi lingkungan perairan. Pemanfaatan lebih lanjut dengan air kelapa dapat mengurangi resiko tersebut. Limbah akhir yang ada pada pengolah dapat dimanfaatkan oleh masyarakat sekitar sebagai pupuk cair untuk menyuburkan tanaman perkebunan yang ada di sekitar mereka.

c. Penggunaan vakuum sealer serta plastik food grade sebagai pengemas ikan.

Plastik yang digunakan memiliki keunggulan dalam hal bentuk yang fleksibel sehingga mudah mengikuti bentuk ikan yang dikemas, berbobot ringan, tidak mudah pecah, bersifat transparan/tembus pandang, mudah diberi label dan dibuat dalam aneka warna, dapat diproduksi secara massal, harga relatif murah. Penggunaan alat vakuum sealer menghasilkan produk yang daya simpannya lebih lama karena sifatnya yang kedap udara.

Tahapan pengemasan sebagai berikut: $\rightarrow$ Ikan fufu yang sudah kering dengan baik didinginkan; $\rightarrow$ Setelah dingin dimasukkan ke dalam plastik; $\rightarrow$ kemudian plastik/kemasan PE disegel dengan vacuum sealer.

\section{Pendampingan}

Pendampingan bertujuan supaya kegiatan pelatihan dan penyuluhan yang sudah diberikan berkesinambungan. Kegiatan pendampingan 
dilakukan sebanyak 2 kali dalam satu bulan selama 8 bulan.

\section{Evaluasi}

Evaluasi akan dilakukan selama 2 bulan dengan membagikan checklist (daftar isian) proses pengolahan ikan cakalang asap yang sesuai dengan teknik penanganan yang baik yaitu mengacu pada prinsip sanitasi dan higiene serta membandingkan (kompilasi) kegiatan yang sebelum dan sesudah menerima penyuluhan dan pelatihan.

Ikan tanpa perendaman pada air kelapa
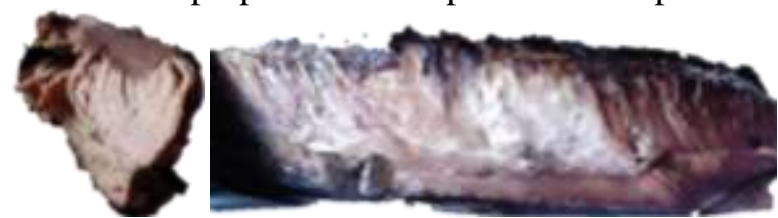

Ikan dengan perendaman pada air kelapa
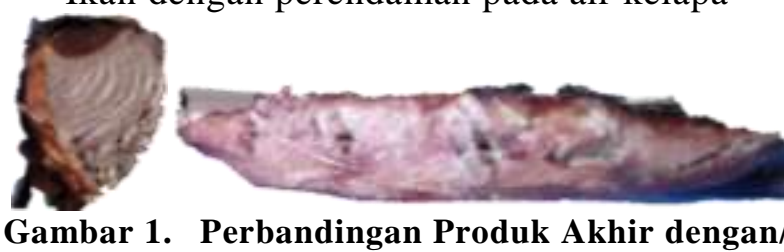

Gambar 1. Perbandingan Produk Akhir dengan/ tanpa Perendaman dengan Air Kelapa.

Pelaksanaan program desiminasi yang berjudul "aplikasi air kelapa sebagai aditif alami bagi peningkatan mutu produk cakalang asap (cakalang fufu) khas Sulawesi Utara" di Kelurahan Molas lingkungan V, tepatnya di pengolahan ikan cakalang $f u f u$, telah dilaksanakan sejak tanggal 11 Oktober 2017 hingga .....

Rumah ikan cakalang fufu yang ada di lingkungan V Kelurahan Molas terbagi dua bagian, yaitu:

\section{a. Ruang pengolahan}

Ruang pengolahan berukuran $10 \times 3,5 \mathrm{~m}$ dengan kondisi lantai yang di cor dengan semen tetapi tidak rata dan kotor. Terbuat dari dinding yang tidak diplester, saluran air kurang rapi, tidak terdapat bak untuk pencucian ikan dan alat yang digunakan dalam pengolahan. Terdapat sebuah WC dimana dinding dan lantai kurang bersih karena lantai dan dinding WC tidak licin (tidak ditehel). Kebersihan WC sangat berpengaruh pada proses pengolahan karena WC tersebut berada dekat dengan ruang pengolahan, yaitu keluar dari WC langsung masuk ke ruang pengolahan. Kondisi ruang pengolahan ikan fufu sebelum dan sesudah prototip teknologi ke masyarakat adalah sebagai berikut:

- Lantai. Lantai di ruang pengolahan tidak memenuhi syarat untuk ruang proses pengolahan ikan, karena hanya terbuat dari cor yang tidak licin dan banyak melekat tanah, yang nantinya akan berdampak pada produk ikan cakalang asap. Cemaran berupa tanah, pasir, kerikil, debu sangat mengganggu sifat inderawi selama dikunyah (ngeres) dan dapat mempengaruhi warna hasil olahan yaitu akan nampak tidak cerah, serta dapat merendahkan nilai estetika hasil olahan. Selain itu tanah merupakan tempat hidup berbagai jenis mikrobia sehingga bila tanah mengotori hasil olahan, terikut pula mikrobia perusak dan patogen yang membahayakan kesehatan. Dalam pelaksanaan program prototipe teknologi pada masyarakat perbaikan lantai menjadi perhatian untuk diperbaiki.

Dinding. Dinding pengolahan belum memenuhi syarat pengolahan hasil perikanan, walaupun sudah terbuat dari susunan konblok tapi belum dibuat licin. Dinding yang tidak licin merupakan peluang sebagai wadah melekatnya debu. Debu tersebut dapat dengan mudah berpindah ke bahan baku ikan yang masih basa sehingga dapat mempengaruhi sanitasi produk. Produk yang tidak saniter merupakan wadah yang baik untuk berkembangnya mikroba patogen. Dalam pelaksanaan program prototip teknologi pada masyarakat, perbaikan dinding menjadi perhatian untuk diperbaiki.

Bak air. Dalam proses pengolahan ikan yang direndam dengan air kelapa sebagai aditif alami, sarana bak sebagai penampungan air kelapa sangat dibutuhkan. Bak yang dibutuhkan adalah bak yang terbuat dari beton dan licin supaya kotoran dari ikan tidak mudah melekat pada bak dan mudah dibersihkan. Selain bak penampungan air kelapa, juga dibuat bak sebagai tempat pencucian ikan dengan air yang mengalir. Kondisi bak dibuat licin dengan memasang tehel dan juga dibuat lubang pembuangan yang dapat diatur buka tutup supaya dengan mudah untuk mengeluarkan air yang kotor. Kedua bak tersebut dipasang pipa air supaya dengan mudah membersihkan bak dan ikan. 
Pengadaan dua buah bak merupakan hal yang dianggap penting sehingga bak tersebut menjadi prioritas pengadaan.

- Meja Pengolahan. Dalam proses pengolahan ikan, meja pengolahan sangat dibutuhkan karena meja tersebut adalah tempat mengolah ikan dari utuh sampai siap diasapi. Proses pengolahan ikan fufu adalah: menyiangi ikan, membelah ikan, mengeluarkan tulang, merendam ikan dalam air kelapa, menjepit dengan bambu dengan tujuan agar memudahkan pada saat proses pengasapan. Pengadaan meja pengolahan menjadi prioritas dalam pelaksanaan program prototipe teknologi pada masyarakat.

- Saluran air. Saluran air adalah salah satu sarana yang sangat menentukan kebersihan suatu perusahaan hasil perikanan sehingga merupakan syarat yang harus dipenuhi dalam usaha pengolahan ikan. Saluran air merupakan wadah jalannya kotoran berupa cairan sebagai limbah hasil pengolahan ikan asap, karena dengan adanya saluran air kotoran limbah cair unit pengolahan ikan dapat dengan mudah dibersihkan lewat saluran tersebut. Syarat saluran air adalah harus licin dan tidak mudah melekatnya kotoran. Agar saluran air memenuhi syarat tersebut maka dalam prototipe teknologi kepada masyarakat perbaikan saluran air dianggap sangat penting.

- Toilet (WC). Dalam suatu unit pengolahan ikan, kebersihan dan kesehatan pekerja pengolah ikan sangat menentukan. Salah satu sarana penunjang yang dibutuhkan pekerja dalam pengolahan ikan adalah toilet. Kebersihan suatu toilet dapat mempengaruhi kesehatan pekerja, untuk itu WC yang memenuhi syarat harus dipenuhi. WC yang baik adalah WC yang mudah dibersihkan, baik dinding, lantai dan kloset. Apalagi kalau posisi WC berada dekat dengan ruang pengolahan ikan. Dalam pelaksanaan prototip teknologi pada masyarakat perbaikan WC menjadi proritas untuk diperbaiki.

- Pengadaan cool box. Cool box adalah sarana yang sangat dibutuhkan dalam suatu unit pengolahan ikan. Adanya cool box dapat mempertahankan kesegaran ikan selama penyimpanan. Penyimpanan ikan dalam cool box tidak dapat dihindari karena musim ikan berfluktuasi, sehingga pada saat musim ikan maka produser ikan fufu akan membeli ikan yang cukup sesuai dengan wadah penyimpanan, karena pada saat tersebut selain ikan mudah didapat juga harganya relatif lebih murah daripada saat tidak musim ikan. Setiaap hari produksi ikan fufu dapat dilaksanakan dengan syarat tersedianya bahan baku ikan. Bahan baku ikan dapat dibeli dalam jumlah yang banyak jika tersedia wadah cool box yang memadai, sehingga penggadaan cool box menjadi prioritas dalam pelaksanaan prototip teknologi kepada masyarakat. Berikut adalah bukti pengadaan cool box.

- Pengadaan Celemek. Celemek adalah salah satu alat yang digunakan oleh pekerja untuk melindungi pakaian dari pengaruh kotoran dari limbah. Dalam pengolahan ikan asap celeme sangat dibutuhkan oleh pekerja untuk melindungi diri dan baju dari darah dan kotoran ikan. Pengadaan celeme untuk pekerja dianggap sangat penting pada prototip teknologi pada masyarakat. Bukti celeme yang disediakan dan digunakan pekerja dapat dilihat pada gambar berikut

- Telenan. Telenan adalah salah satu alat kelengkapan dalam pengolahan ikan terutama dalam unit pengolahan ikan fufu (asap). Telenan berfungsi sebagai tempat landasan ikan pada saat ikan dibelah menjadi ikan bahan baku ikan fufu. Agar telenan tidak berpengaruh pada fisik ikan, dibutuhkan telenan yang kuat, licin tidak mudah terpotong pada saat digunakan untuk sandaran (landasan) membelah ikan. Pengadaan telenan yang memenuhi syarat menjadi prioritas dalam prototip teknologi pada masyarakat. Telenan sebelum dan sesudah prototip dapat dilihat pada gambar berikut.

\section{b. Ruang pengasapan}

Ruang pengasapan terbagi dua ruangan, yaitu ruangan dengan kapasitas ikan asap 300 ekor dan 200 ekor. Ruang pengasapan tidak mengalami perubahan yang menyolok hanya menganti sebagian besi yang sudah rusak dan merapikan tempat pengasapan. Dinding pengasapan sudah disun tela tetapi tidak diplester dengan beton supaya licin karena jika sudah diplester, dinding akan mudah pecah karena panas dari api tempat pengasapan ikan.hal ini terjadi karena dinding tidak lagi berpori sehingga panas pada dinding tidak bisa 
keluar bersama udara dan mengakibatkan dinding pecah.

\section{Fungsi dan Manfaat Produk Teknologi.}

Banyak manfaat yang diperoleh setelah bahan baku ikan direndam dalam air kelapa, yaitu: mengurangi kadar histamin pada ikan (Wonggo, 1995), meningkatkan tekstur, rasa dan warna pada ikan olahan asap (Montolalu, 1995). Histamin adalah senyawa hasil dekarboksilasi dari asam amino histidin. Kandungsn histamin lebih besar dari $100 \mathrm{mg} \%$ pada ikan, dapat menyebabkan alergik dan lebih tinggi akan menyebabkan kematian. Kadar histamin yang tinggi terdapat pada ikan yang sudah menurun kesegarannya, dan hal ini rentan terjadi pada bahan baku ikan $f u f u$ (asap), karena para pengolah ikan umumnya kurang memahami penanganan ikan untuk mempertahankan kesegaran. Penggunaan air kelapa pada perendaman ikan sebagai bahan baku ikan asap akan menurunkan kadar histamin hingga 46\% (Wonggo, 1995).

Perubahan tekstur pada ikan asap setelah direndam dalam air kelapa mengalami perbaikan dibandingkan dengan ikan yang tidak direndam dalam air kelapa. Hal ini terjadi karena adanya proses tekanan osmosa yaitu cairan bergerak dari konsentrasi rendah ke konsentrasi tinggi, yang menyebabkan air dari ikan yang konsentrasi rendah akan keluar ke medium air kelapa yang mempunyai konsentrasi tinggi. Pada saat terjadi kemunduran mutu, senyawa makro molekul pada ikan seperti: protein, lemak dan karbohidrat akan mengalami degradasi akibat enzim dari daging ikan dan bakteri, hal ini akan dihasilkan sejumlah air yang mengisi bagian dari daging karena daging sudah lembek. Kondisi ikan yang demikian jika tidak direndam dalam air kelapa, pada waktu pengasapan air tersebut akan mengambil tempat yang mustinya ditempati oleh daging, akibatnya terbentuk rongga-rongga diantara daging ikan karena sebelum air habis pada saat pengasapan, daging sudah masak terlebih dahulu atau bersamaan, sehingga daging ikan tidak elastik dan menjadi kaku karena sudah masak, sehingga tidak kembali menjadi kompak. Namun hal ini tidak akan terjadi jika bahan baku ikan asap sebelum diasapi direndam terlebih dahulu dalam air kelapa, sehingga air yang ada didalam daging akan keluar dan daging akan kembali seperti awalnya karena masih elastik dan jika diasapi maka daging ikan akan menjadi kompak karena tidak dihalangi oleh air.

Peningkatan rasa pada ikan asap terjadi karena air kelapa banyak mengandung komponen zat gizi yang terlarut didalamnya, seperti gula reduksi sehingga menambah rasa yang enak pada ikan asap, juga kandungan asam amino pada air kelapa lebih baik dari asam amino pada susu sapi, sehingga asam amino tersebut akan memberikan pengaruhi yang positif pada rasa produk ikan cakalang asap. Banyak lagi komponen yang lain seperti mineral makro, mikro dan vitamin yang juga turut mempengaruhi rasa dari ikan cakalang asap yang sebelum diasapi telah direndam dalam air kelapa.

Pewarnaan pada bahan baku ikan asap tidak dapat dihindari untuk mengelabui pembeli, karena warna yang menarik menunjukkan ikan mempunyai tingkat kesegaran tinggi. Di pasaran untuk mendapatkan ikan segar yang bermutu baik sangat sukar, karena ikan segar mempunyai harga yang bersaing jika di jual segar, sedangkan pengusaha ikan asap membutuhkan ikan yang murah dan kurang memperhatikan kesegaran ikan yang akan diolah, akibatnya untuk mengecoh para pembeli maka ikan tersebut diberi pewarna, namun dosis yang dipakai tidak terukur walaupun pewarna yang digunakan adalah pewarna makanan. Bahaya bahan makanan tambahan yang sintetik pada kesehatan adalah akan terakumulasi dalam tubuh jika dikonsumsi secara terus menerus dan akan berdampak negatif yaitu sebagai pemicu terjadinya kanker. Untuk menghindari agar hal ini tidak terjadi, maka penambahan bahan sintetik sangat dihindari dan sebagai alternatif sangat diharapkan menggunakan bahan tambahan yang alami yang tidak berdampak pada kesehatan, yaitu merendam bahan baku ikan ke dalam air kelapa. Manfaat air kelapa dalam perendaman ikan sebagai bahan baku ikan asap adalah memperbaiki warna ikan asap. Air kelapa mengandung sejumlah gula reduksi yang sangat mempengaruhi dalam pembentukan warna coklat keemasan pada ikan asap. Warna coklat terjadi karena reaksi antara gula dari air kelapa dengan protein yang berasal dari ikan yang mengalami pemanasan, sehingga tanpa penggunaan pewarna sintetik, maka warna dari ikan cakalang asap akan berwarna cokelat keemasan, dimana warna ini yang diharapkan para pembeli, karena mirip dengan ikan segar. 
Ikan yang segar masih mengandung banyak glikogen dan jika dibuat ikan asap, glikogen akan pecah menjadi molekul glukosa, bereaksi dengan protein daging ikan membentuk warna coklat keemasan. Penggunaan air kelapa sebagai bahan perendaman bahan baku ikan asap sebagai alternatif yang aman untuk menghasilkan warna yang diinginkan oleh masyarakat, karena memiliki kemiripan dengan bahan baku ikan segar.

\section{Dampak ekonomi dan Sosial.}

Harga suatu bahan pangan sangat ditentukan oleh mutu bahan pangan tersebut. Aplikasi air kelapa dalam peningkatan mutu ikan asap sangat jelas, yaitu menurunkan kadar histamin, meningkatkan rasa, warna dan tekstur dari bahan baku ikan asap. Secara kasat mata mutu ikan asap dinilai dari tekstur, rasa dan warna. Jika komponen mutu tersebut terpenuhi, maka ikan asap tersebut mempunyai tawaran yang lebih tinggi dibandingkan dengan ikan asap yang bermutu rendah. Umumnya pembeli di jaman sekarang mementingkan mutu walaupun harga agak mahal dibandingkan harga rendah tapi mutu juga rendah.

Produk ikan asap yang direndam sebelum diasapi, menghasilkan produk yang aman dan tidak mengganggu kesehatan manusia karena ikan tidak alergik, tekstur, rasa dan warna yang tidak menipu masyarakat pembeli, sehingga bahan baku ikan asap yang direndam dengan air kelapa akan memberikan dampak yang positif pada masyarakat yang mengkonsumsi ikan tersebut. Mengkonsumsi ikan yang bermutu jelek akan berdampak negatif pada masyarakat dan menimbulkan kegelisahan karena kesehatan terganggu.

\section{Kontribusi Terhadap Sektor Lain.}

Air kelapa yang digunakan dalam perendaman bahan baku ikan asap diambil di pasar pada pedagang kelapa cukur. Di pasar, air kelapa sebagai limbah dari pedagang kelapa cukur membuang limbah air kelapa secara tidak rapi karena hanya dibuang di tanah apalagi kalau tanah tersebut kering. Limbah kelapa cukur yang dibuang sebarangan akan mempengaruhi lingkungan baik dari segi bau, BOD dan estetika lingkungan sehingga dapat berdampak pada kesehatan masyarakat di pasar dan menimbulkan ketidaknyamanan. Pemanfaatan air kelapa dari limbah kelapa cukur akan memberikan dampak positif terhadap lingkungan di pasar, karena air kelapa sebagai limbah kelapa cukur sudah tidak dibuang sembarangan dan hal ini sangat membantu para pedagang kelapa cukur karena sudah membantu dalam penanganan limbah kelapa cukur. Pemanfaatan air kelapa yang merupakan limbah dari pedagang kelapa cukur adalah mencegah polusi lingkungan, membantu pedagang kelapa cukur dalam penanganan limbah, juga menyediakan aditif alami bagi pengusaha ikan asap.

Pengolahan ikan cakalang asap menghasilkan limbah padat dan cair. Limbah padat berupa insang, sisik dan tulang, sedangkan limbah cair berupa darah. Secara sederhana, insang, sisik dan tulang dapat dijadikan tepung dan dapat dimanfaatkan sebagai bahan tambahan pada pakan ternak. Sedangkan cucian daging ikan sebagai limbah cair dapat dimanfaatkan sebagai pupuk pada tanaman. Jika hal ini dapat dipahami dengan baik, maka lingkungan yang bersih dapat tercapai, tanaman menjadi subur dan produksi meningkat, dan ternak peliharaan menjadi sehat dan produksi meningkat dan dapat mendatangkan pendapatan yang meningkat.

\section{Kendala/Hambatan.}

Hal yang sangat ditakuti dalam suatu usaha dan tindakan apapun adalah hambatan dan kendala. Apalagi hal yang baru untuk merubah kebiasaan para pengusaha ikan yang selama ini sudah terbiasa dan merasa nyaman tanpa memperhitungkan kemajuan yang akan diperoleh. Kebiasaan meneruskan secara turun temurun sangat kuat sehingga butuh waktu dan cara untuk meyakinkan para pengusaha untuk merubah kebiasaan yang selama ini sangat tidak menguntungkan. Sebagai contoh adalah penggunaan pewarna yang mustinya tidak terjadi, tetap digunakan walaupun menggunakan bahan pewarna makanan namun konsentrasi yang tidak terukur, sehingga hal ini sangat berbahaya pada kesehatan konsumen.

Meletakkan bahan baku ikan di lantai, yang mestinya tidak terjadi karena lantai mudah dihinggapi kuman dan kotoran. Bekerja tanpa menggunakan baju apalagi celemeh, kebiasaan bercerita sementara bekerja, karena mulut adalah sebagai sumber kuman dan disarankan menggunakan masker supaya produk tidak terkena ludah maupun air liur manusia.

\section{Tindaklanjut}


Pemecahan suatu masalah, sangat membutuhkan suatu solusi yang tepat dan afektif guna penyelesaian masalah yang dihadapi. Penyuluhan pendampingan dan pelatihan merupakan suatu metoda yang tepat. Dalam penyuluhan membutuhkan waktu yang cukup untuk menyadarkan, menginformasikan dan mengajak dengan cara yang santun dan bijaksana, agar pengusaha tertarik dan yakin tentang benarnya prototip teknologi yang diterapkan. Dalam penyuluhan secara perlahan, benar dan tepat untuk meyakinkan bahwa peranan air kelapa benar-benar mempunyai banyak pengaruh yang positif terhadap bahan baku ikan jika direndam dalam air kelapa. Penjelasan secara logis tentang pengaruh air kelapa terhadap tekstur, warna, rasa dan penampakan, agar peserta penyuluhan dapat menerima dengan baik dan dapat mempercayai serta masuk akal tentang ilmu yang diajarkan dan bukan hayalan belaka. Penyuluhan, pelatihan dan pendampingan dalam waktu yang cukup, akan terjalin hubungan antara peserta dan penyuluh. Hubungan yang baik antara peserta dan penyuluh akan menghasilkan pengaruh yang positif. Jika sudah ada pengaruh yang positif, maka ilmu yang diajarkan akan diserap walaupun membutuhkan waktu. Jadi dalam hal ini penyuluh diharapkan mampu merebut atau merangkul dengan baik hati para peserta penyuluh supaya terjalin hubungan yang positif. Jika hal ini sudah terjadi, maka ilmu apapun yang akan ditransfer kepada masyarakat akan mendapat respon yang positif. Faktor penting dalam penyuluhan adalah penerimaan masyarakat tentang kehadiran penyuluh, karena sebagus apapun ilmu yang akan ditransfer tetapi kehadiran penyuluh tidak diterima, maka keberhasilan penyuluhan akan menjadi gagal.

\section{KESIMPULAN DAN SARAN}

\section{Kesimpulan}

Hasil pengamatan dan pengalaman di lapangan, para pengusaha pengolah ikan fufu mempunyai kebiasaan yang perlu dilestarikan dan juga ada hal-hal membutuhkan waktu yang cukup untuk mengubah kebiasaan yang selama ini mereka lakukan dimana kebiasaan ini tidak perlu ditiru. Ada dua faktor yang dapat ditarik kesimpulan, faktor yang positif dan faktor yang negatif, yaitu:

1. Faktor positif.

Sistem kerja di tempat pengusaha ikan cakalang fufu yang ada di Cempaka adalah sistem kekeluargaan dan mereka bekerja seperti pada rumah sendiri dengan pembagian tugas masingmasing. Pembagian tugas dikerjakan dengan rasa tanggung jawab dan tidak perlu menunggu perintah. Hal ini dapat dipelihara dengan baik sehingga tercipta kondisi kerjsa yang saling menguntungkan.

2. Faktor Negatif.

Kebersihan kurang mendapat perhatian dari para pekerja baik kebersihan diri maupun kebersihan lingkungan. Pekerja umumnya tidak menggunakan celemeh dan masker dalam bekerja. Bahan baku ikan hanya diletakkan dilantai, air yang digunakan tidak saniter dan digunakan secara berulang. Hal ini terjadi karena kurangnya pengetahuan tentang pentingnya sanitasi dan higiene.

3. Teknologi yang ditransfer ke masyarakat baru pada tahap memperoleh, menyadari dan menerima tentang peranan air kelapa dalam memperbaiki mutu ikan cakalang asap hal ini membutuhkan waktu untuk penyuluhan yang teratur dan berkelanjutan.

\section{Saran}

Perlu adanya penyuluhan yang berkelanjutan yang teratur untuk mengsukseskan keberhasilan prototip teknologi ke masyarakat, untuk itu dibutuhkan waktu untuk melanjutkan program ini.

\section{DAFTAR PUSTAKA}

Afrianto, E dan E. Liviawaty, 1989. Pengawetan Dan Pengolahan Ikan. Kanisius. Yogyakarta.

[DKP, Sulut]. Dinas Kelautan dan Perikanan Sulawesi Utara. Laporan Tahunan Dinas Kelautan dan Perikanan Propinsi Sulawesi Utara.

Dotulong V. 1985. Pengaruh Bahan Pengasap, Lama Pengasapan dan Lama Penyimpanan pada Suhu Kamar terhadap Mutu Ikan Cakalang (Katsuwonos pelamis L) Asap

Fawzya, YN. Murniyati dan Suryaningrum TD. 2011. Persyaratan Pengolahan Produk Perikanan. Balai Besar Penelitian dan Pengembangan Pengolahan Produk dan Bioteknologi Kelautan dan Perikanan. Kementerian Kelautan dan Perikanan.

Gue, H. 2003. Warna Alami Pada Ikan Asap Yang Dibuat Dari Bahan Baku Dengan Tingkat Kesegaran Dan Lama Pengasapan Yang Berbeda Serta Kesukaan Terhadap Ikan Asap Yang Diberi Zat Pewarna. Skripsi. Fakultas Perikanan Dan Ilmu Kelautan. Unsrat. Manado. 
[JICA] Japan International Cooperation Agency. 2009. Indonesian fisheries statistic index 2009. Ministry of Marine Affairs and Fisheries. http://www.dkp.go.id/ index.php/ind/news/1125/jica-download-book [26 April 2013]

[LPPM Unsrat] Lembaga Penelitian dan Pengabdian kepada Masyarakat. 2016. Laporan Akuntabilitas Kinerja Instansi Pemerintah (LAKIP) Tahun 2015
Lembaga Penelitian dan Pengabdian kepada Masyarakat Universitas Sam Ratulangi Manado.

Wibowo, S. 2000. Industri Pengasapan Ikan. Penerbit PT. Penebar Swadaya. Jakarta.

Winarno, F.G. 1980. Kimia Pangan. PusBangTepa Food Technologi Development Center. Institut Pertanian Bogor. 